\title{
Pengaruh Kualitas Produk Terhadap Minat Beli Konsumen Pada Home Industri Pia Deisy Desa Kapitu Kecamatan Amurang Barat
}

\author{
Nikita Karundeng \\ Johny A.F. Kalangi \\ Olivia Walangitan \\ Jurusan Ilmu Administrasi, Program Studi Administrasi Bisnis \\ Fakultas Ilmu Sosial dan Politik, Universitas Sam Ratulangi \\ Email:nikyy19972@gmail.com
}

\begin{abstract}
This study aims to determine whether Product Quality has an effect on Consumer Buying Interest. Speaking with quality and buying interest is certainly very tied to marketing. The essence of marketing according to Daryanto (2011) "marketing is a social and managerial process where individuals and groups get their needs and desires by creating, offering, and exchanging something of value with each other". This type of research is quantitative research with data analysis techniques using a skla likert research instrument, test validity, reliability, simple linear regression analysis and hypothesis testing. Based on the results of the study the influence of product quality is a variable that does not affect consumer buying interest. Then it can be concluded that product quality does not significantly influence consumer buying interest. If the quality of the product is good, there will be buying interest and consumers will feel satisfied. In this case, Pia Deisy's business must further improve product quality so that it will be more attractive and will have a good impact on Pia Deisy's home business.
\end{abstract}

Keywords: Product Quality, Buying Interest

\section{Pendahuluan}

Perkembangan dunia bisnis yang semakin maju menyebabkan persaingan yang semakin meningkat. Konsumen dalam hal ini menjadi pemeran utama akan menentukan produk yang diinginkan sehingga kualitas produk merupakan hal yang penting dan perlu diperhatikan setiap perusahaan jika ingin mendapatkan hasil yang maksimal serta dapat bersaing di pasaran. Konsumen sangat kritis dalam menentukan produk yang akan di konsumsi, konsumen selalu ingin mendapatkan produk yang berkualitas baik. produsen memiliki peran yang besar dalam membuat sebuah produk yang mempunyai nilai tinggi dan dapat dipercaya oleh konsumen sehingga nantinya akan tercipta minat untuk membeli produk tersebut. Ketika konsumen melihat produk yang di tawarkan tentunya konsumen tersebut akan berpikir untuk mencoba produk yang di tawarkan sehingga tercipta keyakinan dan keputusan untuk mencoba sebuah produk yang ditawarkan. Home Industri atau usaha rumahan Pia Deisy ini terletak di Desa Kapitu Kecamatan Amurang Barat. Menawarkan berbagai macam varian rasa dari produk kue kering PIA seperti rasa keju, cokelat, temo, dan kacang. Banyak 
sekali peluang bisnis rumahan sekarang ini dan salah satunya usaha home industri pia deisy kapitu. Berbagai macam usaha yang diciptakan dan dikembangkan dengan inovasi dan kreatifitas yang tinggi. Terlebih sekarang ini ditambah dengan teknologi yang sangat maju yang dapat ikut serta mengembangkan usaha-usaha rumahan yang ada. Sebagai pelaku usaha rumahan tentunya hal ini akan semakin mempermudah dalam melakukan pemasaran serta memperluas jaringan lewat publik media online.

Kualitas produk ialah harus memiliki mutu sebagai suatu dasar strategi bisnis yang menyediakan barang atau jasa untuk memuaskan konsumen, sehingga nantinya akan tercipta minat beli. Minat beli akan muncul dengan sendirinya dalam diri seseorang. Merasa tertarik, terdorong terhadap apa yang dilihat dan berencana untuk membeli produk yang dilihat atau ditawarkan dan nantinya akan dikonsumsi. Sebagai penelitian dalam skripsi ini adalah Home industri Pia Deisy Kapitu Kecamatan Amurang Barat. Pia Deisy ini merupakan bisnis yang memiliki pasar yang sangat luas sekaligus tingkat persaingan yang tinggi, keadaan ini mempertegas bahwa usaha makanan sepeti kue kering Pia dapat bertumbuh kedepannya, namun untuk mempertahankan kepercayaan konsumen terhadap produk Pia ini maka harus membutuhkan tata kelola yang baik. Usaha rumahan yang berlokasi di desa kapitu ini didirikan oleh ibu deisy pada tahun 2010 memiliki delapan orang karyawan yang bekerja dalam bidang masing-masing seperti ada yang membuat adonan, membentuk adonan, membakar adonan, melayani konsumen dan lain sebagainnya. Pia deisy ini buka mulai dari pukul 7 pagi sampai pukul 10 malam. Harga dari pia ini persatuannya adalah 1000 rupiah harga yang relative terjangkau. Usaha yang didirikan oleh ibu deisy ini tidaklah mudah berbagai macam rintangan dan tantangan datang menghampiri dalam membangun usaha ini namun karena tekad dan pantang menyerah usaha Pia Deisy ini dapat bertahan hingga saat ini.

\section{Metodologi Penelitian}

Metode yang digunakan dalam penelitian ini adalah metode deskriptif kuantitatif, Penelitian ini terdiri dari dua variabel yaitu kualitas produk dan minat beli. Desain penelitian ini menjelaskan metode penelitian yang digunakan dan bagaimana penelitian tersebut dilakukan. Metode penelitian diartikan sebagai suatu penyelidikan yang sistematis untuk meningkatkan sejumlah pengetahuan, juga merupakan suatu usaha yang sistematis dan terorganisasi untuk menyelidiki masalah tertentu yang memerlukan jawaban, yang didasari oleh asumsi-asumsi dasar, pandangan-pandangan filosofi dan ideologi pernyataan isu yang dihadapi.

Dimensi Kualitas Produk menurut Tjiptono (2008) dalam Jurnal Administrasi Bisnis 15 (1), 2014. ada delapan dimensi kualitas produk :

(1) Performance (Kinerja)

Performance berkaitan dengan karakteristik operasi dasar dari suatu 
produk, yang meliputi merek, atributatribut yang dapat di ukur.

(2) Durability (Daya tahan)

Berkaitan dengan berapa lama atau umur sebuah produk yang bersangkutan dapat bertahan sebelum akhirnya produk tersebut diganti. Umumnya semakin besar frekuensi pemakain konsumen atas suatu produk maka akan semakin besar pula daya produk tersebut.

(3) Conformance To Specifications (Kesesuain dengan spesifikasi)

Maksutnya adalah sejauh mana karakteristik operasi dasar dari suatu produk dapat memenuhi spesifikasi tertentu dari konsumen atau dengan kata lain tidak di temukan cacat pada produk tersebut.

(4) Features (Fitur)

Fitur, merupakan karakteristik sebuah produk yang dirancang untuk menyempurnakan fungsi produk atau menambah ketertarikan konsumen atas produk tersebut.

(5) Reability (Reabilitas)

Yaitu probabilitas bahwa produk yang bersangkutan akan bekerja dengan baik dan memuaskan ataupun tidak dalam periode waktu tertentu. Pada umumnya semakin kecil kemungkinan terjadinya kerusakan pada sebuah produk maka itu berarti produk tersebut dapat diandalkan.

(6) Aesthetics (Estetika)

Estetika berkaitan dengan bagaimana tampilan produk yang bersangkutan.

(7) Perceived quality (Kesan kualitas)
Sering disebut sebagai hasil dari pemakain pengukuran yang dilakukan secara tidak langsung karena ada kemungkinan bahwa konsumen tidak mengerti atau kurang informasi terhadap produk yang bersangkutan.

(8) Serviceability (Kemampuan melayani)

Mencakup kemudahan dan kecepatan untuk direparasi, serta kompetensi dan keramah tamahan staf layanan.

Tahap-tahap Minat Beli Konsumen dapat kita lihat pada model AIDA (Attention, Interest, Desire, dan Action) yang dikembangkan oleh Kotler (2009: 180) dalam Khairani (2018);

(1) Attention Tahap ini merupakan tahap awal dalam menilai suatu produk atau jasa sesuai dengan kebutuhan calon pelanggan, selain itu calon pelanggan juga mempelajari produk atau jasa yang ditawarkan.

(2) Interest, Dalam tahap ini calon pelanggan mulai tertarik untuk membeli produk atau jasa yang ditawarkan, setelah mendapatkan informasi yang lebih terperinci mengenai produk atau jasa yang ditawarkan.

(3) Desire, calon pelanggan mulai memikirkan serta berdiskusi mengenai produk atau jasa yang ditawarkan, karena hasrat dan keinginan untuk membeli mulai timbul. Dalam tahapan ini calon pelanggan sudah mulai berminat terhadap produk atau jasa yang ditawarkan. Tahap ini ditandai dengan munculnya minat yang kuat dari calon pelanggan untuk membeli 
dan mencoba produk atau jasa yang ditawarkan.

(4) Action Pada tahap ini calon pelanggan telah mempunyai kemantapan yang tinggi untuk membeli atau menggunakan produk atau jasa yang ditawarkan.

\section{Hasil Penelitian Dan Pembahasan}

Dalam penelitian ini terdapat uji validitas dimana uji validitas ini mengukur sah atau tidaknya suatu kuesioner. kedua Teknik analisis yaitu analisis regresi linear sederhana ini regresi yang memiliki satu variabel inependen dan satu variabel dependen.

\section{Uji Validitas Kehandalan Reliability}

Berdasarkan hasil uji validitas kehandalan pada tabel 4 menunjukan bahwa nilai korelasi product moment ( $\mathrm{r}$ hitung) untuk masing-masing item peryataan lebih besar dari nilai $\mathrm{r}$ tabel 0 , 220 (tarif signifikan 5\%) sehingga semua item dari pertanyaan tersebut dinyatakan valid dan dapat digunakan untuk penelitian.

\section{(1) Uji Reliabilitas Kualitas Produk (X) dan Minat Beli (Y)}

Berdasarkan hasil penelitian yang di peroleh dari software spss version 25 , maka dapat diketahui bahwa variabel yang digunakan adalah reliabel. nilai Cronbach's Alpha 0,727 > dari 0,60 maka data reliabel dimana butiran pertanyaan pada variabel kualitas produk dapat diterima oleh responden. nilai Cronbach's Alpha 0,748 > 0,60 maka data reliabel diatas menunjukan bahwa butriran pertanyaan pada variabel kualitas produk dapat diterima oleh responden. Masing-masing variabel memiliki nilai diatas 0,60 .

\section{(2) Analisis Regresi Linear Sederhana}

Maka didapat hasil sebgai berikut :

Dimana $Y=18,442+(-0,36)$

Model persamaan regresi linier sederhana dari hasil SPSS tersebut yaitu

Unstandardized Coefficients adalah sebagai berikut:

$$
\mathrm{Y}=\mathrm{a}+\mathrm{BX}
$$

Berdasarkan hasil tersebut maka dapat dapat diartikan Nilai constan sebesar 18,442 memberikan pengertian bahwa jika faktor Kualitas Produk (X) tidak dilakukan atau sama dengan nol (0) maka besarnya minat beli (Y) sebesar 18,442. Kualitas produk $(\mathrm{X})$ memberikan nilai negatif sebesar 0,036). Artinya setiap $1 \%$ perubahan Kualitas Produk (X) akan mempengaruhi Minat Beli (Y) sebesar 0,36\% maka pengaruh terhadap minat beli akan mengalami penurunan.

\section{(3) Uji Korelasi dan Determinasi}

Berdasarkan hasil tabel dengan bantuan program SPSS version 25 maka dapat di ketahui hasil koefisien korelasi atau $\mathrm{R}$ adalah sebesar 0,060. Angka tersebut berarti hubungan antara kualitas produk dan terhadap minat beli konsumen adalah yaitu sangat rendah 6.0.

(a) Nilai korelasi atau $\mathrm{R}$ 0,060, dapat diartikan bahwa hubungan antara variabel X (Kualitas produk) terhadap $\mathrm{Y}$ (Minat beli) adalah sangat rendah 
karena nilai $\mathrm{R}$ atau koefisien korelasi berada antara 0,000-0,199. Maka dapat diartikan hubungan antara variabel $\mathrm{X}$ (Kualitas produk) terhadap Y (Minat beli) Sangat rendah. Dengan kata lain jika Kualitas produk semakin menurun pada Pia Deisy Kapitu maka minat beli akan semakin menurun.

(b) Nilai $\mathrm{R}$ square atau koefisien determinasi sebesar 0,004 yang menunjukan bahwa $0.4 \%$ Pengaruh (Kualitas produk) terhadap variabel (Minat Beli) sangat rendah. Sementara sisanya sebesar 99,6 dapat dipengaruhi oleh variabel lainnya yang tidak diteliti seperti Harga karena harga produk sama pentingnya dengan merancang produk itu sendiri. Meski mempunyai produk yang baik, bila harga yang ditawarkan tidak tepat maka konsumen enggan membelinya. Tempat usaha karena pemilihan lokasi sangat penting terhadap usaha yang di jalankan letak yang strategis dan mudah dilihat serta akses jalan yang mudah dapat menarik konsumen untuk datang akan tetapi kalau malah sebaliknya pemilihat tempat yang tidak tepat bisa saja konsumen tidak tertarik untuk datang.

\section{Pembahasan}

Berdasarkan hasil pengelolaan data diperoleh kedua variabel yaitu kualitas produk dan minat beli, Karakteristik responden berdasarkan jenis kelamin menunjukan bahwa kebribadian responden menunjukan perempuan lebih menyukai produk kue kering pia deisy dibandingkan laki-laki dikarenakan banyak konsumen seperti ibu-ibu yang sering membeli produk pia deisy ini. Dari segi umur responden dengan usia 30-40 tahun bisa dikatakan minat dengan produk kue kering ini. Berdasarkan karakteristik pekerjaan yang paling minat dengan pia deisy ini yaitu wirausaha karena cukup banyak juga usaha seperti warung-warung kecil yang menjual kembali produk pia deisy ini.

Berdasarkan hasil pegelolaan data tentang pengaruh Kualitas produk merupakan variabel yang tidak berpengaruh terhadap minat beli konsumen Pia Deisy Kapitu. Untuk lebih jelasnya akan dibahas sebagai berikut :

Kualitas Produk. Berdasarkan hasil penelitian diketahui bahwa dari hasil uji korelasi dan determinasi menunjukan nilai korelasi atau $\mathrm{R}$ adalah 0,060 dapat di artikan bahwa hubungan antara variabel $\mathrm{X}$ (kualitas produk) terhadap Y (minat beli) adalah sangat rendah. Selain itu hasil uji validitas dikatakan valid dikarenakan semua butir pertanyaan pada nilai correct item-total correlation berada di atas $r$ tabel yang berada pada taraf signifikan lima persen dan uji reliabel dikatakan reliabel karena hasil dari cronbach alpha.

Dimana kualitas produk merupakan suatu dorongan kepada konsumen untuk membeli sebuah produk dalam jangka panjang. Ikatan seperti ini memungkinkan Usaha rumahan Pia Deisy ini untuk memahami dengan saksama harapan dari konsumen serta kebutuhan dari konsumen. Dengan demikian usaha rumahan Pia Deisy 
Kapitu dapat meningkatkan Minat beli dari konsumen.

Kualitas produk menjadi peran utama untuk meningkatkan minat beli konsumen yang maksimal dan dapat dipercaya.

Minat Beli data yang diperoleh pada penelitian di ketahui bahwa dari semua responden konsumen Pia Deisy Kapitu menyatakan setuju pada kuesioner yang telah dibagikan peneliti. Selain itu hasil uji validitas dikatakan valid dikarenakan semua butir peryataan pada nilai correct item-total correlation berada di atas $r$ tabel yang berada pada taraf signifikan lima persen dan uji reliabel dikatakan reliabel karena hasil dari cronbach alpha.

Kualitas produk yang baik akan menarik hati pelanggan untuk membeli produk tersebut. Karena makin baik kualitas produk yang di tawarkan maka minat beli dari konsumen akan meningkat, dan pastinya konsumen akan merasa puas bila keinginannya telah terpenuhi, dengan produk yang di konsumsi. Minat beli dapat di pengaruhi oleh beberapa faktor yaitu antara lain kualitas produk, pelayanan, penetapan harga.

\section{Pengaruh Kualitas Produk Tehadap Minat Beli Konsumen}

Untuk menunjang Minat Beli konsumen maka salah satu upaya yang harus dilakukan oleh Usaha rumaha Pia Deisy kapitu adalah perlu memberikan kualitas produk yang benar-benar dapat dipercaya, sebab dengan adanya peningkatan dalam hal ini kualitas produk yang baik maka akan mempengaruhi minat beli konsumen tentunya.

Penelitian ini berbeda dengan penelitian sebelumnya karena hasil penelitian ini menunjukan kualitas produk tidak berpengaruh terhadap minat beli konsumen Akan tetapi dapat dipengaruhi oleh variabel lain seperti harga, promosi, dan tempat. Hal ini terjadi karena variabel Kualitas produk terhadap Minat beli konsumen dengan hasil uji korelasi koefisien determinasi. Ini berarti indikator dari kualitas produk yang diukur merupakan faktor yang menentukan Minat beli konsumen Pia Deisy Kapitu. Sedangkan sisanya dapat dipengaruhi oleh variabel apapun, seperti promosi, harga, tempat, suasana di dalam tempat usaha dan lain sebagainya. Artinya meskipun kualitas produk Pia Deisy ini tidak berpengaruh, pelanggan tetap saja datang dikarenakan distribusi jawaban dari 80 orang responden tentang minat beli yang memiliki nilai tertinggi yaitu menyukai produk.

\section{Kesimpulan}

Berdasarkan hasil penelitian dan pembahasan, maka dapat ditarik kesimpulan sebagai berikut:

Uji korelasi dan determinasi melalui hasil uji SPSS version 25 menujukan bahwa nilai korelasi atau $\mathrm{R}$ 0,060 dapat diartikan bahwa Kualitas produk dan Minat beli adalah sangat rendah. Dengan kata lain jika kualitas produk menurun maka minat beli dengan sendirinya akan mengalami penurunan. Hal tersebut ditujukan dari hasil uji. Kualitas produk yang baik merupakan 
proses terwujudnya minat beli konsumen. Penelitian ini membuktikan bahwa kualitas produk menjadi faktor yang paling berpengaruh dalam menjual barang atau jasa yang ditawarkan.

Apabila suatu produk tersebut berada pada tingkat kualitas produk yang baik disegi rasa, meranik untuk dibeli dan sesuai dengan keinginan konsumen maka hal itu sangat berpengaruh nantinya terhadap tingginya minat beli konsumen Pia Deisy Kapitu. Diambil kesimpulan bahwa variabel kualitas produk berpengaruh secara signifikan namun pengaruhnya pada variabel lain seperti harga, promosi, tempat. variabel yang sangat penting dan perlu diperhatikan. Usaha Pia Deisy ini harus melakukan langkah yang tepat untuk mengembangkan suatu usaha, dikarenakan kualitas produk yang baik akan berpotensi menarik konsumen baru.

\section{Saran}

Berdasarkan hasil dan pembahasan maka Peneliti mengharapkan agar penelitian ini dapat berguna bagi penelitian lanjutan atas topik yang serupa.

Peneliti berharap hasil penelitian ini dapat menimbulkan rasa keingin-tahuan untuk penelitian lanjutan, dan peneliti merekomendasikan kepada home industri Pia Deisy Kapitu untuk memperhatikan secara seksama pentingnya kualitas produk.

Unsur kualitas produk karena faktor tersebut memiliki pengaruh besar didalam proses minat beli konsumen. Peneliti menyarankan dengan mengadakan wawancara atau penyebaran kuesioner yang lebih luas guna mendapatkan hasil yang maksimal serta dapat menambahkan variabel lainnya agar dapat memperoleh hasil penelitian yang lebih luas cakupannya serta dapat mendukung untuk penelitianpenelitian selanjutnya.

\section{Daftar Pustaka}

Daryanto. 2011. Manajemen Pemasaran. Bandung. PT Sarana Tutorial Nurani Sejahtera.

Yusri, Abdilah. 2016. Pengaruh Kualitas Produk dan Kualitas Jasa Terhadap Kepuasan Pelanggan. Jurnal Administrasi Bisnis (JAB). Universitas Briwijaya Malang Vol 35. http://journal.ub.ac.id.

Arief Adi Satria. 2017. Pengaruh Harga, Promosi, dan kualitas Produk Terhadap Minat Beli Konsumen pada Perusahaan A-36. Jurnal Manajemen dan Bisnis Universitas Ciputra Surabaya Vol 2. http://journal.uc.ac.id.

Shaharudin, M Rizaimy. 2011. The Relationship Between Product Quality And Purchase Intention: The Case of Malaysia's National Motorcycle/Scooterm Manufacturer. African Journal of Business Management Vol 5 (20).

Tjiptono (2008). Pengaruh Kualitas Produk dan Kualitas Pelayanan Terhadap Kepuasan Pelanggan dalam membentuk loyalitas pelanggan (Studi pada pelanggan McDonald's MT. Haryono Malang) Jurnal Administrasi Bisnis 15 (1), 2014. 
Zulia Khairani. (2018), Model AIDA Efektivitas Promosi Melalui Instagram pada UMKM Sektor Makanan dan Minuman di Kota Pekanbaru. Jurnal Benefita: Ekonomi Pembangunan, Manajemen Bisnis dan Akuntansi 3 (2) 239-242, 2018. 